\title{
Sustainable Entrepreneurship Utopian Idea or a New Business Model for the 21st Century?
}

\author{
Letycja Sołoducho-Pelc (iD
}

Uniwersytet Ekonomiczny we Wrocławiu

\section{Introduction}

Human activities causing global warming, water pollution, and the exploitation of natural resources have been rapidly increasing. That is why, in the 21st-century, expectations for enterprises have changed, meaning they are now seeking a balance between economic, social and environmental benefits. Enterprises are required to skillfully reconcile conflicting interests arising at the interface between business and society and business and environment. There is a pressing need for enterprises to be involved in solving climate-related and social problems, with the new term, "economic patriotism" being a manifestation of a responsible approach to business activity. Issues related to environmental degradation pose new challenges for enterprises and management concepts in line with the idea of green and sustainability are part of the answer to worldwide disruptions. Sustainable entrepreneurship is a new area of research that combines the notion of entrepreneurship and sustainable development. This idea has attracted the interest of a wide range of stakeholders such as economists, society, and politicians. This interest is due to the rapid increase in environmental problems that affect the whole world ${ }^{1}$. The new concept of sustainable entrepreneurship requires a balance between profit orientation, and social and environmental responsibility. This idea uses unexplored possibilities to solve a broad spectrum of problems. By sustainable entrepreneurship one understands that it is our duty to maintain the environment for future generations and for the good of society and the environment itself. Therefore, a modern company's

1 D.A. Shepherd, H. Patzelt, The new field of sustainable entrepreneurship: Studying entrepreneurial action linking 'what is to be sustained' with 'what is to be developed', "Entrepreneurship: Theory \& Practice” 2011, vol. 35, no. 1, pp. 137-163. 
goal is not only development in the economic sphere but also social and environmental. The article starts with a review of the concept of sustainable entrepreneurship and its use in the context of entrepreneurial management. The core section presents research directions and the disadvantages of sustainable entrepreneurship. Finally, the article presents conclusions, implications for practice, and recommendations for further research.

The method of research for this paper takes the form of a systematic, evidenceinformed literature review. The papers presented in this review were selected from those published in leading academic journals specializing in entrepreneurship and management. Using the Scopus, Web of Science, Emerald, and Wiley databases, articles in the area of strategic entrepreneurship were identified. According to the Scopus database, 352 documents were published in the years 2002 to 2020 which have the phrase "strategic entrepreneurship" in the title. By classifying publications in terms of the research area, the following main result areas were obtained: Business, Management (31.8\%), Social Sciences (14.9\%), Economics, Economy (14.3\%), Environmental Science (13.9\%), Energy (9.9\%). The three most prestigious publications in the area of sustainable entrepreneurship are presented in Table 1.

Table 1. Most frequently cited publications in the field of sustainable entrepreneurship

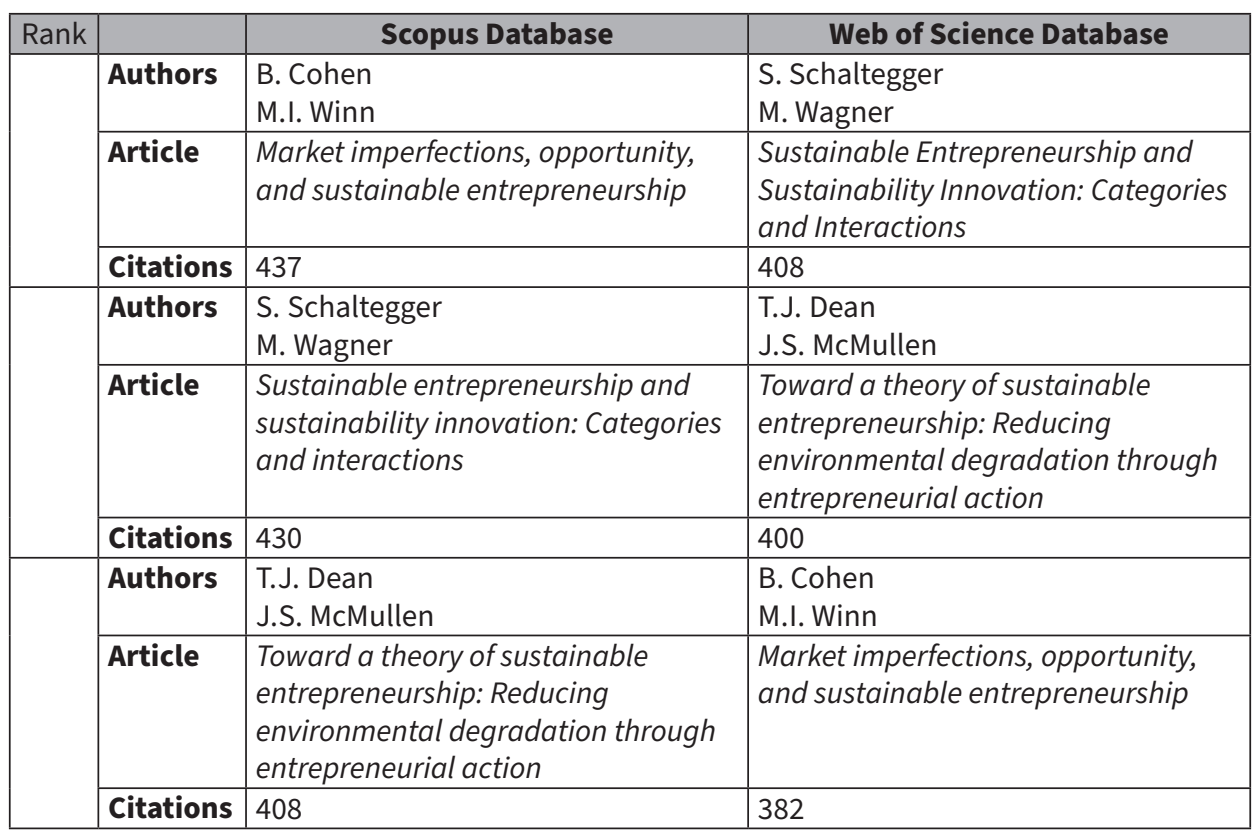

Source: own work. 
As can be seen, three authors' papers play a primary role in the development of research on sustainable development. In the presented works, sustainable entrepreneurship plays a crucial role in market imperfection, sustainability innovation, and environmental degradation.

\section{Theoretical framework - Identifying the meaning of sustainable entrepreneurship}

Traditionally, entrepreneurship focused on creating economic value. In the new approach, however, economic value is a means to achieve other objectives. Value creation is not just about financial and profit measures. The combination of economic benefit and soft social, environmental, and economic values is characteristic of this approach ${ }^{2}$.

Since the presentation of the first concepts of sustainable entrepreneurship, doubts have developed around its definition ${ }^{3}$. Sustainable entrepreneurship is about discovering, creating, and using entrepreneurial opportunities that contribute to sustainable development by generating social and environmental benefits ${ }^{4}$. Sustainable entrepreneurship can be defined as a process that recognises and uses entrepreneurial opportunities in the context of social and environmental problems ${ }^{5}$. Sustainable entrepreneurship is defined as a process of solving social and environmental problems that are oriented towards sustainable development ${ }^{6}$. Entrepreneurship is sustainable when the value created benefits the environment, society, and the company

2 B. Cohen, M.I. Winn, Market imperfections, opportunity and sustainable entrepreneurship, "Journal of Business Venturing" 2007, vol. 22, pp. 29-49; T.J. Dean, J.S. McMullen, Toward a theory of sustainable entrepreneurship: Reducing environmental degradation through entrepreneurial action, "Journal of Business Venturing" 2007, vol. 22, no. 1, pp. 50-76; A.M. Vuorio, K. Puumalainen, K. Fellnhofer, Drivers of entrepreneurial intentions in sustainable entrepreneurship, "International Journal of Entrepreneurial Behavior \& Research" 2018, vol. 24 no. 2, pp. 359-381; Ch. Vallaster et al., Responsible entrepreneurship: outlining the contingencies, "International Journal of Entrepreneurial Behaviour \& Research" 2019, vol. 25, no. 3, pp. 538-553.

3 C. Vallaster et al., Responsible entrepreneurship...

4 F. Tilley, W. Young, Sustainability Entrepreneurs - Could they be the True Wealth Generators of the Future?, "Greener Management International" 2009, vol. 55; D.F. Pacheco, T.J. Dean, D.S. Payne, Escaping the green prison: entrepreneurship and the creation of opportunities for sustainable development, "Journal of Business Venturing” 2010, vol. 25 no. 5, pp. 464-480.

5 F.M. Belz, J.K. Binder, Sustainable entrepreneurship: A convergent process model, "Business Strategy and the Environment" 2017, vol. 26, no. 1, pp. 1-17.

6 S. Schaltegger, E.G. Hansen, F. Lüdeke-Freund, Business models for sustainability: Origins, present research, and future avenues, "Business Strategy and the Environment" 2016, vol. 29, no. 1 , pp. 3-10. 
economically ${ }^{7}$. As for competitiveness, sustainable entrepreneurship is the creation of competitive, environmentally friendly products, services, and production meth$\mathrm{ods}^{8}$. A characteristic feature of the definition is the use of entrepreneurship to create products, services, and production methods that ensure the reconciliation of two priority objectives: achieving profits and caring for the environment ${ }^{9}$.

It is worth noting that in the literature we several terms occur which refer to the idea of sustainable entrepreneurship. These are: "ecopreneurship", "environmental entrepreneurship", "sustainable development entrepreneurship", "sustainable entrepreneurs", "green entrepreneurship"10.

This innovative view of entrepreneurship has initiated the emergence of new types of entrepreneurship. Researchers refer to concepts such as social entrepreneurship, environmental entrepreneurship, and sustainable entrepreneurship ${ }^{11}$. In environmental entrepreneurship, the necessity to solve environmental problems has initiated action, whereas in social entrepreneurship the primary motivator is achieving social goals ${ }^{12}$. Sustainable entrepreneurship covers the need for action concerning both the environment and society. Therefore, sustainable entrepreneurship includes social and environmental entrepreneurship ${ }^{13}$. This concept involves creating value in three areas: economics, society, and the environment ${ }^{14}$. In sustainable entrepreneurship, the

7 F. Boons, F. Lüdeke-Freund, Business models for sustainable innovation: state-of-the-art and steps towards a research agenda, "Journal of Cleaner Production" 2013, vol. 45, pp. 9-19; T. Rantala et al., Identifying Strategies for Sustainable Entrepreneurship, Innovation for Sustainability, Palgrave Macmillan, Cham 2019, pp. 213-229.

8 T.J. Dean, J.S. McMullen, Toward a theory of sustainable entrepreneurship...; J.K. Hall, G.A. Daneke, M.J. Lenox, Sustainable development and entrepreneurship: Past contributions and future directions, "Journal of Business Venturing" 2010, vol. 25, no. 5, pp. 439-448.

9 J.G. Garmann, L. Olaison, B.M. Sørensen, Put your style at stake: A new use of sustainable entrepreneurship, "Organization Studies" 2018, vol. 39, no. 2-3, pp. 397-415.

10 L. Linnanen, An insider's experiences with environmental entrepreneurship, "Greener Management International" 2002, vol. 38 no. 2, pp. 71-80; S.E.A. Dixon, A. Clifford, Ecopreneurship - a new approach to managing the triple bottom line, "Journal of Organizational Change Management” 2007, vol. 20 no. 3, pp. 326-345; S. Schaltegger, M. Wagner, Sustainable entrepreneurship and sustainability innovation: categories and interactions, "Business Strategy and the Environment" 2011, vol. 20, no. 4, pp. 222-237; D. Fischer, R. Mauer, M. Brettel, Regulatory focus theory and sustainable entrepreneurship, "International Journal of Entrepreneurial Behavior \& Research" 2018, vol. 24, no. 2, pp. 408-428.

11 J. Mair, I. Marti, Social entrepreneurship research: A source of explanation, prediction, and delight, “Journal of World Business” 2006, vol. 41, no. 1, pp. 36-44.

12 T. Rantala et al., Identifying Strategies..., pp. 213-229.

13 K. Hockerts, R. Wüstenhagen, Greening Goliaths versus emerging Davids - Theorizing about the role of incumbents and new entrants in sustainable entrepreneurship, "Journal of Business Venturing" 2010, vol. 25, no. 5, pp. 481-492.

14 H.I. Stål, K. Bonnedahl, Conceptualizing strong sustainable entrepreneurship, "Small Enterprise Research" 2016, vol. 23, no. 1, pp. 73-84. 
attention is on solving social problems. Close cooperation with the social environment and the implementation of a social mission is practiced. This approach builds a sense of social belonging and supports the development of social capital15.

Sustainable entrepreneurship is a dynamic and interdisciplinary concept. The attention of entrepreneurs is shifted towards a comprehensive approach to the environment, taking into account the concern for future generations. Understanding the meaning behind this idea requires reference to other areas. These include economics, business management, sociology, psychology, anthropology, and tourism ${ }^{16}$.

The concept of sustainable entrepreneurship appeared as a response to new expectations regarding entrepreneurship ${ }^{17}$. Initially, entrepreneurship was understood as contributing to economic growth, innovation, and employment creation ${ }^{18}$. However, the assessment of business activity limited to the economic perspective was insufficient. The problems of the modern world have forced a change in the perception of entrepreneurship ${ }^{19}$. It is now recognized that entrepreneurship can contribute to solving both environmental problems and challenging social issues ${ }^{20}$.

Entrepreneurship and sustainable development have been integrated into the idea of a sustainable enterprise being focused on the 3P: People, Profit, Planet ${ }^{21}$. In 1994, Elkington introduced the term "triple bottom line" to refer to enterprises when their development of higher business value are assessed in a broad 3P perspective. The decisions made in each of these areas relate to the triad: people, profit, planet $^{22}$ :

15 F. Luís et al., Conditions supporting entrepreneurship and sustainable growth, "International Journal of Social Ecology and Sustainable Development (IJSESD)" 2017, vol. 8, no. 3, pp. 67-86.

16 V. Ratten et al., Sustainable Entrepreneurship: The Role of Collaboration in the Global Economy, [in:] V. Ratten et al., Sustainable Entrepreneurship, The Role of Collaboration in the Global Economy, Springer, Cham 2019, pp. 1-7.

17 P. Woodfield, C. Woods, D. Shepherd, Sustainable entrepreneurship: another avenue for family business scholarship?, "Journal of Family Business Management” 2017, vol. 7, no. 1, pp. 122-132.

18 S. Shane, S. Venkataraman, The promise of entrepreneurship as a field of research, "Academy of Management Review" 2000, vol. 25, no. 1, pp. 217-226.

19 L. Ploum et al., Toward a validated competence framework for sustainable entrepreneurship, "Organization \& Environment" 2018, vol. 31, no. 2, pp. 113-132; C.G. Johnsen, L. Olaison, B.M. Sørensen, Put your style at stake: A new use of sustainable entrepreneurship, "Organization Studies" 2018, vol. 39, no. 2-3, pp. 397-415.

20 P.D. Keogh, M.J. Polonsky, Environmental commitment: a basis for environmental entrepreneurship?, "Journal of Organizational Change Management" 1998, vol. 11, no. 1, pp. 38-49.

$21 \mathrm{H}$. Bonnet et al., Teaching sustainable entrepreneurship to engineering students: the case of Delft University of Technology, "European Journal of Engineering Education" 2006, vol. 31, no. 2, pp. 155-167.

22 J. Elkington, Enter the triple bottom line, [in:] A. Henriques, J. Richardson, The triple bottom line, Routledge, London 2004, pp. 1-16; P. Muñoz, B. Cohen, Entrepreneurial narratives in sustainable Venturing: Beyond people, profit, and planet, "Journal of Small Business Management" 2018, vol. 56, pp. 154-176. 
- Profit - Economic Sustainability - It measures the profit and loss of a company in an organization.

- People - Social Sustainability - Determines how socially responsible the organization was during its operations.

- Planet - Environmental Sustainability - Indicates the company's degree of responsibility for the environment.

Sustainable entrepreneurship combines profit with the creation of social and environmental values to care for the well-being of future generations. Therefore, it is crucial to reconcile divergences regarding the achievement of economic goals with social and environmental problems. Integrating economic, social, and ecological goals over a long time horizon is the goal ${ }^{23}$. Significant in this concept is the issue of the durability of solutions, their renewal, and protection. Thus, they are the power to create new sustainable solutions ${ }^{24}$.

Instead of the most important company goals being profits, in sustainable entrepreneurship, strategic goals related to nature protection, life support sources protection, and community protection. Benefits are defined as both business and non-economic profits. These include benefits for society, security and respect for the environment, and economic viability from a strategic perspective. The critical assumption is to assess goals and profits from the view of the situation of future generations ${ }^{25}$.

The vision of challenges for business and the environment vary. In normal business operations, environmental degradation is considered mainly from the risk perspective. Risk includes lawsuits and the negative image of the organization. In sustainable entrepreneurship, however, the deterioration of the natural environment is treated differently ${ }^{26}$. The climate crisis (the effect of human activity and the most critical development challenge) generates new business opportunities.

Entrepreneurs should strive to limit the destruction of the natural environment, while being aware that the implementation of new technologies and solutions for the reuse of waste represents new trends in business. Optimal use of resources, restoration of resources, or recycling of waste are ideas for business operations ${ }^{27}$. New business opportunities are orienting at introducing social and environmental changes ${ }^{28}$.

23 D. Fischer, R. Mauer, M. Brettel, Regulatory focus theory...

24 D.F. Pacheco, T.J. Dean, D.S. Payne, Escaping the green prison...

25 D.A. Shepherd, H. Patzelt, The new field...

26 J.G. York, S. Venkataraman, The entrepreneur-environment nexus: Uncertainty, innovation, and allocation, "Journal of Business Venturing" 2010, vol. 25, no. 5, pp. 449-463.

27 J.C. Garmann, L. Olaison, B.M. Sørensen, Put your style at stake...

28 D.Y. Choi, E.R. Gray, The venture development processes of "sustainable" entrepreneurs, "Management Research News" 2008, vol. 31, no. 8, pp. 558-569. 
Despite this interpretation of entrepreneurship under the banner of sustainable entrepreneurship, it is not a threat in the sense of limiting the activities of companies. Indeed, entrepreneurial initiatives can help preserve the natural environment and social balance 29 . This concept has the potential to have a mobilizing effect on social and environmental activities. However, an overly optimistic impression of sustainable entrepreneurship as a panacea for the problems of the modern world is misleading.

When examining sustainable entrepreneurship, one should pay attention to the unique role of the entrepreneur. According to the assumption of sustainable entrepreneurship, the "new" entrepreneur can change the negative impact of economic activities on the climate. Sustainable entrepreneurs are those whose ambition is to support changes in the field of sustainable development. They believe that their actions have a significant impact on achieving the result of an overall balanced effect and see the opportunity to derive a positive effect on sustainable development. They are the initiator and catalyst of actions ${ }^{30}$. They act in liaison with other entities, such as people, resources, networks, spaces, money, ideas, artifacts, and nature. The distinguishing feature of sustainable entrepreneurs is their passion and willingness to reconcile business issues with environmental challenges ${ }^{31}$.

Researchers point to the importance of a sustainable entrepreneur in initiating the transformation and implementation of sustainable practices and processes, as sustainable entrepreneurs can influence other industry players to make a change. The effectiveness of such entrepreneurial activities is determined by the overlapping of corporate goals with the needs and values of the client group. Therefore, consumers should change their purchasing decisions, since it is necessary for customers to care whether the producer of the goods and services acts with respect for the natural environment, allowing sustainable entrepreneurs to compete based on products, services, organisational solutions, and environmentally friendly technologies. Explaining the success of sustainable entrepreneurs, scientists point to the impact of four factors: innovation orientation, achievement motivation, resource use, and environmental sustainability ${ }^{32}$. Sustainable entrepreneurship, therefore, can be indicated as a process in the preparedness to build a competitive advantage as a response to global warming 33 .

29 A. Pastakia, Grassroots ecopreneurs: change agents for a sustainable society, "Journal of Organizational Change Management" 1998, vol. 11, no. 2, pp. 157-173.

30 R. Hanohov, L. Baldacchino, Opportunity recognition in sustainable entrepreneurship: an exploratory study, "International Journal of Entrepreneurial Behavior \& Research" 2018, vol. 24, no. 2, pp. 333-358.

31 K. Poldner, P. Shrivastava, O. Branzei, Embodied multi-discursivity: An aesthetic process approach to sustainable entrepreneurship, "Business \& Society” 2017, vol. 56, no. 2, pp. 214-252.

32 C. Vallaster et al., Responsible entrepreneurship...

33 K. Poldner, P. Shrivastava, O. Branzei, Embodied multi-discursivity... 


\section{Trends in and contributions to sustainable entrepreneurship research}

Most research in the field of sustainable entrepreneurship is theoretical and conceptual. Although attitude, knowledge, skills, and competences in entrepreneurship have been studied for many years, they represent a new area of research for sustainable development management, as the value and motives of a sustainable entrepreneur are different from ordinary entrepreneurs ${ }^{34}$. Sustainable entrepreneurship concerns people who are not motivated only by personal economic gain. Other factors play an essential role: knowledge, entrepreneurship orientation, sustainability, and sustainable development ${ }^{35}$. Among the motives researchers indicate pro-ecological values, compassion, and moral commitment, and a strong sense of responsibility. In sustainable enterprises, the essential goals relate to five primary motivators: green values, passion, being one's own boss, recognizing the market gap, and earning a living ${ }^{36}$. Being guided by company growth and promoting sustainable development goals is characteristic of the creative phase of creating ideas. In the implementation process, entrepreneurs focus on growth and risk ${ }^{37}$.

Researching competencies relevant for sustainable entrepreneurship highlighted: systems thinking competencies, normative competencies, foresighted thinking competencies, interpersonal competencies, whereas strategic action competencies plays a lesser role 38 .

Sustainable entrepreneurship is a field of research combining innovation, entrepreneurship, and sustainable development. Until now, little attention has been paid to understand the innovative processes involved in solving environmental and social problems. Such innovation processes are referred to as being "socially oriented", as they require responsible innovation ${ }^{39}$.

34 H.C. Hooi et al., The functional role of entrepreneurial orientation and entrepreneurial bricolage in ensuring sustainable entrepreneurship, "Management Research Review" 2016, vol. 39, no. 12 , pp. $1616-1638$.

35 P. Muñoz, D. Dimov, The call of the whole in understanding the development of sustainable ventures, "Journal of Business Venturing" 2015, vol. 30, no. 4, pp. 632-654.

36 J. Kirkwood, S. Walton, What motivates ecopreneurs to start businesses?, "International Journal of Entrepreneurial Behavior \& Research" 2010, vol. 16, no. 3, pp. 204-228; A. Fayolle, F. Liñán, The future of research on entrepreneurial intentions, "Journal of Business Research" 2014, vol. 67, no. 5, pp. 663-666; A.M. Vuorio, K. Puumalainen, K. Fellnhofer, Drivers of entrepreneurial intentions...

37 D. Fischer, R. Mauer, M. Brettel, Regulatory focus theory...

38 K. Poldner, P. Shrivastava, O. Branzei, Embodied multi-discursivity...

39 C. Vallaster et al., Responsible entrepreneurship... 
The focus of our research is sustainable development in the context of SMEs and new enterprises. Smaller entities recognize the need for sustainable development and display increasing interest in standards, certificates, and codes of conduct that are expected to bring many benefits. The issue of eco-orientation is extensively studied within the context of the benefits and effects for SMEs. Advantages such as cost saving, improved reputation, and customer satisfaction are beyond doubt. The satisfaction of a wide range of stakeholders, the introduction of sustainable solutions, and building social value are essential, if these elements are to build the basis for long-term cooperation. Research has failed to fully identify the factors that stimulate SMEs to achieve sustainable development goals ${ }^{40}$.

The entrepreneurial process sets a new direction for a sustainable venture. Sustainable entrepreneurs determine a social or ecological problem. They then create an idea for a business opportunity which results from the motivation to solve a specific problem. They develop solutions, finance and establish a sustainable enterprise.

Scientists indicate that the process of sustainable entrepreneurship remains mostly unexplored ${ }^{41}$, and despite the growing attention on sustainable entrepreneurship, knowledge about combining business, economic, social, and environmental issues is limited. According to the available research results, a sustainable decision-making process should be motivating, goal-oriented, value-based, and specific solutionoriented $^{42}$, and it should result in a balanced decision-making process.

\section{Criticism of sustainable entrepreneurship and directions for further research}

In response to criticism of sustainable development in connection with entrepreneurship, terms such as "corporate greening", "corporate environmentalism" have arisen ${ }^{43}$. Research in the field of sustainable entrepreneurship highlights two

40 C. Pomare, A Multiple Framework Approach to Sustainable Development Goals (SDGs) and Entrepreneurship, "Entrepreneurship and Sustainable Development Goals (Contemporary Issues in Entrepreneurship Research)" 2018, vol. 8, pp. 11-31.

41 G.T. Lumpkin et al., Entrepreneurial processes in social contexts: how are they different, if at all?, "Small Business Economics" 2013, vol. 40, no. 3, pp. 761-783; F.M. Belz, J.K. Binder, Sustainable entrepreneurship...

42 P. Muñoz, A cognitive map of sustainable decision-making in entrepreneurship: A configurational approach, "International Journal of Entrepreneurial Behavior \& Research" 2018, vol. 24, no. 3, pp. 787-813.

43 A. Crane, Corporate greening as moralization, "Organization Studies" 2000, vol. 21, no. 4, pp. 673-696; C. Wright, D. Nyberg, D. Grant, Hippies on the third floor: Climate change, narrative identity, and the micro-politics of corporate environmentalism, "Organization Studies" 2012, vol. 33, no. 11, pp. 1451-1475. 
opposing assumptions. These are connected to business operations and sustainable development, a dual approach which gives rise to conflicts. Each decision is linked to the triad: profit, people, the planet, which hinders the implementation of the idea in practice.

Challenges related to environmental degradation are a global phenomenon. Climate risk management is vital at the world, regional, and national economy level since economic systems in the modern world are interrelated and interdependent. The attitude of entrepreneurs resulting from a change in thinking about the environment can change the world for the better. However, it is difficult to imagine that an individual approach can stop and reverse the destruction of the world's environments 44 . Therefore, treating entrepreneurship in sustainable entrepreneurship as knight in shining armour who will save the world from destruction seems naive.

The decision on ecological sustainability is not evident to the entrepreneur. Having to choose between economic growth and respect for the environment often results in deciding in favor of the predatory growth of enterprises. This conflict between capitalism, which aims to maximize profit, and concern for the environment and meeting the needs of future generations, seems difficult to resolve.

A critical review of the literature on sustainable entrepreneurship has inspired further research. Limited progress has been made in understanding the process of sustainable entrepreneurship and the factors shaping this entrepreneurship, and several problems have been identified that set the direction for future research. Research is therefore needed into how fostering and acting on sustainable entrepreneurship may be best supported across eight key areas:

- Measuring and assessing the value of sustainable entrepreneurship has not yet been studied. It is difficult to indicate precise measures to evaluate the activities of sustainable entrepreneurs. Estimation of benefits and cost assessment, degree of sustainability of entrepreneurial initiatives has not been assessed.

- The sustainable entrepreneurship process, stages, and effects require further research. The differences between traditional entrepreneurial and sustainable processes deserve a closer look.

- Strategies at the company level and a functional approach to implementing this idea have not yet been the subject of much research.

- The capital and investment needs related to activities pursuing social and environmental goals are not recognized. The development of sustainable entrepreneurship depends on the investment offer and research and development activity.

44 C. Wright et al., Future imaginings: organizing in response to climate change, "Organization" 2013, vol. 20, no. 5, pp. 647-658. 
- Methods for creating sustainable entrepreneurship, barriers for entrepreneurs on the road to sustainable development, incentives to support sustainable business practices require further research.

- Social and ecological partnership, cooperation within networks, measurement of social and environmental benefits (effects) of cooperation determine the directions of further research.

- Classification of sustainable enterprise is lacking. The criterion may be the level of commitment and focus on the use of sustainable entrepreneurship in business ventures. It can be assumed that different categories of entrepreneurs are not equally involved in sustainable entrepreneurship.

- Problems like pro-social and pro-environmental motivation, willingness to solve socio-ecological problems, belief in their effectiveness in solving global problems remain unsolved.

The implementation of the concept of sustainable entrepreneurship meets with the growing interest of theoreticians and business practitioners. Further research in this area is necessary to move from the concept of "ideal" enterprise to the practice of sustainable entrepreneurship.

\section{Conclusion}

Entrepreneurs predominantly focus on making money. However, companies will have to adapt to the reduced availability of natural resources. In addition, changes in society are needed to adopt pro-social and pro-environmental measures. The implementation of sustainable entrepreneurship has a chance to help protect social and environmental resources and preserve their value for present and future generations. Especially when we assume that environmental problems result from the wrong concept of entrepreneurship. Sustainable entrepreneurship is a step towards the idea of a green economy. In this concept, it is essential to distinguish a profitoriented entrepreneur from a responsible entrepreneur creating value for society and the environment (Figure 1). Sustainable entrepreneurship applies to entrepreneurs operating with passion as ethical entrepreneurs earning money while respecting green values.

It can be assumed that besides building value, sustainable entrepreneurship can generate other benefits. The need for stability and security is of increasing importance in the modern world. Value and protection for stakeholders can be critical factors for implementing sustainable entrepreneurship.

In addition to the initiatives aimed at improving the social situation and environmental changes, it is vital to develop informed individuals and groups of people through education. Entrepreneurship belongs to the canon of subjects implemented 
at various levels of education around the world. This new direction of research sets in motion the promotion of knowledge about sustainable entrepreneurship. It is an initiative already implemented in the EU. In the 2019/2020 training year, the Minister of Education in the Italian government, Fioramonti, introduced the subject of changes in the environment and sustainable development ${ }^{45}$. Sustainable development and climate issues are, therefore, becoming an essential point in the modern educational model.

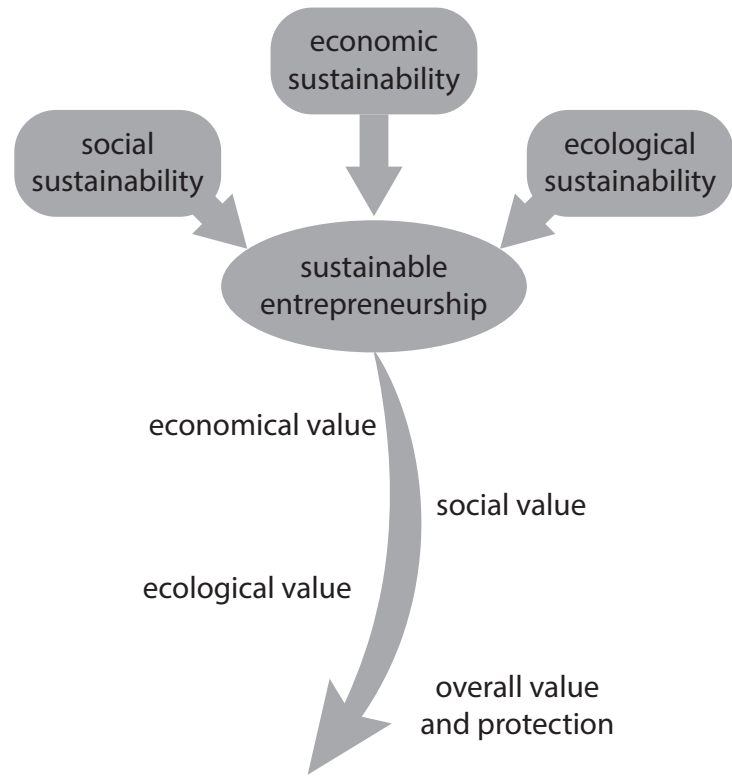

Figure 1. The unique concept value-creating and protection in sustainable entrepreneurship

Source: own work.

Conclusions suggest that the concept of sustainable entrepreneurship is not widely used. And it is in need of further research and development in practice. To implement this idea with due care, it is necessary to understand the broad context in the long term. Is sustainable entrepreneurship a choice or a necessity? This will bring into confrontation a normal approach to business with an unconventional strategy that comes from the "heart".

45 Włochy: Szkoły będq uczyć o zmianach klimatu. Obowiq̨zkowo, https://www.rp.pl/Ekolo gia/191109744-Wlochy-Szkoly-beda-uczyc-o-zmianach-klimatu-Obowiazkowo.html (accessed: 23.12.2019). 
References

Belz F.M., Binder J.K., Sustainable entrepreneurship: A convergent process model, "Business Strategy and the Environment" 2017, vol. 26, no. 1, pp. 1-17.

Bonnet H., Quist J., Hoogwater D., Spaans J., Wehrmann C., Teaching sustainable entrepreneurship to engineering students: the case of Delft University of Technology, "European Journal of Engineering Education" 2006, vol. 31, no. 2, pp. 155-167.

Boons F., Lüdeke-Freund F., Business models for sustainable innovation: state-of-the-art and steps towards a research agenda, "Journal of Cleaner Production" 2013, vol. 45, pp. 9-19.

Choi D.Y., Gray E.R., The venture development processes of "sustainable" entrepreneurs, "Management Research News" 2008, vol. 31, no. 8, pp. 558-569.

Cohen B., Winn M.I., Market imperfections, opportunity, and sustainable entrepreneurship, "Journal of Business Venturing" 2007, vol. 22, pp. 29-49.

Crane A., Corporate greening as moralization, "Organization Studies" 2000, vol. 21, no. 4, pp. 673-696.

Dean T.J., McMullen J.S., Toward a theory of sustainable entrepreneurship: Reducing environmental degradation through entrepreneurial action, "Journal of Business Venturing" 2007, vol. 22, no. 1, pp. 50-76.

Dixon S.E.A., Clifford A., Ecopreneurship - a new approach to managing the triple bottom line, "Journal of Organizational Change Management" 2007, vol. 20, no. 3, pp. 326-345.

Elkington J., Enter the triple bottom line, [in:] A. Henriques, J. Richardson, The triple bottom line, Routledge, London 2004, pp. 1-16.

Fayolle A., Liñán F., The future of research on entrepreneurial intentions, "Journal of Business Research" 2014, vol. 67, no. 5, pp. 663-666.

Fischer D., Mauer R., Brettel M., Regulatory focus theory and sustainable entrepreneurship, "International Journal of Entrepreneurial Behavior \& Research" 2018, vol. 24, no. 2. pp. 408-428.

Garmann J.G., Olaison L., Sørensen B.M., Put your style at stake: A new use of sustainable entrepreneurship, "Organization Studies" 2018, vol. 39, no. 2-3, pp. 397-415.

Hall J.K., Daneke G.A., Lenox M.J., Sustainable development and entrepreneurship: Past contributions and future directions, "Journal of Business Venturing" 2010, vol. 25, no. 5, pp. 439-448.

Hanohov R., Baldacchino L., Opportunity recognition in sustainable entrepreneurship: an exploratory study, "International Journal of Entrepreneurial Behavior \& Research" 2018, vol. 24, no. 2, pp. 333-358.

Hockerts K., Wüstenhagen R., Greening Goliaths versus emerging Davids - theorizing about the role of incumbents and new entrants in sustainable entrepreneurship, "Journal of Business Venturing" 2010, vol. 25, no. 5, pp. 481-492.

Hooi H.C., Ahmad N.A., Amran A., Rahman S.A., Sarkis J., The functional role of entrepreneurial orientation and entrepreneurial bricolage in ensuring sustainable entrepreneurship, "Management Research Review" 2016, vol. 39, no. 12, pp. 1616-1638.

Johnsen C.G., Olaison L., Sørensen B.M., Put your style at stake: A new use of sustainable entrepreneurship, "Organization Studies" 2018, vol. 39, no. 2-3, pp. 397-415.

Keogh P.D., Polonsky M.J., Environmental commitment: a basis for environmental entrepreneurship?, "Journal of Organizational Change Management" 1998, vol. 11, no. 1, pp. 38-49.

Kirkwood J., Walton S., What motivates ecopreneurs to start businesses?, "International Journal of Entrepreneurial Behavior \& Research" 2010, vol. 16, no. 3, pp. 204-228.

Linnanen L., An insider's experiences with environmental entrepreneurship, "Greener Management International" 2002, vol. 38, no. 2, pp. 71-80. 
Luís F., Joao J., Nunes F., Nunes S., Ratten V., Conditions supporting entrepreneurship and sustainable growth, "International Journal of Social Ecology and Sustainable Development (IJSESD)" 2017, vol. 8, no. 3, pp. 67-86.

Lumpkin G.T., Moss T.W., Gras D.M., Kato S., Amezcua A.S., Entrepreneurial processes in social contexts: how are they different, if at all?, "Small Business Economics" 2013, vol. 40, no. 3, pp. 761-783.

Mair J., Marti I., Social entrepreneurship research: A source of explanation, prediction, and delight, "Journal of World Business" 2006, vol. 41, no. 1, pp. 36-44.

Muñoz P., A cognitive map of sustainable decision-making in entrepreneurship: A configurational approach, "International Journal of Entrepreneurial Behavior \& Research" 2018, vol. 24, no. 3, pp. 787-813.

Muñoz P., Cohen B., Entrepreneurial narratives in sustainable Venturing: Beyond people, profit, and planet, "Journal of Small Business Management" 2018, vol. 56, pp. 154-176.

Muñoz P., Dimov D., The call of the whole in understanding the development of sustainable ventures, "Journal of Business Venturing" 2015, vol. 30, no. 4, pp. 632-654.

Pacheco D.F., Dean T.J., Payne D.S., Escaping the green prison: entrepreneurship and the creation of opportunities for sustainable development, "Journal of Business Venturing" 2010, vol. 25 , no. 5, pp. 464-480.

Pastakia A., Grassroots ecopreneurs: change agents for a sustainable society, "Journal of Organizational Change Management" 1998, vol. 11, no. 2, pp. 157-173.

Ploum L., Blok V., Lans T., Omta O., Toward a validated competency framework for sustainable entrepreneurship, "Organization \& Environment" 2018, vol. 31, no. 2, pp. 113-132.

Poldner K., Shrivastava P., Branzei O., Embodied multi-discursivity: An aesthetic process approach to sustainable entrepreneurship, "Business \& Society" 2017, vol. 56, no. 2, pp. 214-252.

Pomare C., A Multiple Framework Approach to Sustainable Development Goals (SDGs) and Entrepreneurship, "Entrepreneurship and Sustainable Development Goals (Contemporary Issues in Entrepreneurship Research)" 2018, vol. 8, pp. 11-31.

Rantala T., Sunila M., Ukko J., Rantanen H., Identifying Strategies for Sustainable Entrepreneurship, Innovation for Sustainability, Palgrave Macmillan, Cham 2019.

Ratten V., Jones P., Braga V., Marques C.S., Sustainable Entrepreneurship: The Role of Collaboration in the Global Economy, [in:] V. Ratten, P. Jones, V. Braga, C.S. Marques, Sustainable Entrepreneurship, The Role of Collaboration in the Global Economy, Springer, Cham 2019, pp. 1-7.

Schaltegger S., Wagner M., Sustainable entrepreneurship and sustainability innovation: categories and interactions, "Business Strategy and the Environment" 2011, vol. 20, no. 4, pp. 222-237.

Schaltegger S., Hansen E.G., Lüdeke-Freund F., Business models for sustainability: Origins, present research, and future avenues, "Business Strategy and the Environment" 2016, vol. 29, no. 1 , pp. 3-10.

Shane S., Venkataraman S., The promise of entrepreneurship as a field of research, "Academy of Management Review" 2000, vol. 25, no. 1, pp. 217-226.

Shepherd D.A., Patzelt H., The new field of sustainable entrepreneurship: Studying entrepreneurial action linking 'what is to be sustained' with 'what is to be developed', "Entrepreneurship Theory and Practice" 2011, vol. 35, no. 1, pp. 137-163.

Stål H.I., Bonnedahl K., Conceptualizing strong sustainable entrepreneurship, "Small Enterprise Research" 2016, vol. 23, no. 1, pp. 73-84.

Tilley F., Young W., Sustainability Entrepreneurs - Could they be the True Wealth Generators of the Future?, "Greener Management International" 2009, vol. 55, pp. 79-92.

Vallaster C., Kraus S., Kailer N., Baldwin B., Responsible entrepreneurship: outlining the contingencies, "International Journal of Entrepreneurial Behavior \& Research" 2009, vol. 25, no. 3, pp. 538-553. 
Vuorio A.M., Puumalainen K., Fellnhofer K., Drivers of entrepreneurial intentions in sustainable entrepreneurship, "International Journal of Entrepreneurial Behavior \& Research" 2018, vol. 24, no. 2, pp. 359-381.

Włochy: Szkoły będq uczyć o zmianach klimatu. Obowiq̨zkowo, https://www.rp.pl/Ekologia/19 1109744-Wlochy-Szkoly-beda-uczyc-o-zmianach-klimatu-Obowiazkowo.html (accessed: 23.12.2019).

Woodfield P., Woods C., Shepherd D., Sustainable entrepreneurship: another avenue for family business scholarship?, "Journal of Family Business Management" 2017, vol. 7, no. 1, pp. 122-132.

Wright C., Nyberg D., Grant D., Hippies on the third floor: Climate change, narrative identity, and the micro-politics of corporate environmentalism, "Organization Studies" 2012, vol. 33, no. 11, pp. 1451-1475.

Wright C., Nyberg D., De Cock C., Whiteman G., Future imaginings: organizing in response to climate change, "Organization" 2013, vol. 20, no. 5, pp. 647-658.

York J.G., Venkataraman S., The entrepreneur-environment nexus: Uncertainty, innovation, and allocation, “Journal of Business Venturing” 2010, vol. 25, no. 5, pp. 449-463.

\section{Abstract}

Entrepreneurial activities are seen as important to business, society, environment. The purpose of this paper is to give an up-to-date assessment of the key topics discussed in the literature on sustainable entrepreneurship. It has become a more accessible, and essential, topic in academic literature and practice. Nowadays, enterprises are required to reconcile contradictions arising at the interface between: business - society and business - environment. Sustainable entrepreneurship is a new area of research that combines the concept of sustainable development and entrepreneurship. This is due to the rapid increase in the environmental problems that affect the whole world. Sustainable entrepreneurship is about discovering, creating, and using entrepreneurial opportunities that contribute to sustainable development by generating social and environmental benefits for society.

The article presents the background, achievements, and current trends in sustainable entrepreneurship. The vast majority of research results in the field of sustainable entrepreneurship are of a conceptual nature. One should also be aware of the overly optimistic approach to the idea of sustainable entrepreneurship as a panacea for social and environmental problems of the modern world. Nevertheless, this concept has the potential to mobilize social and environmental activities. The practice of sustainable entrepreneurship is poorly understood. Further research in this area is necessary to move from the mere concept of an ideal enterprise to the practical implementation of sustainable entrepreneurship.

As this paper is a literature review, a systematic literature review is conducted to assess new contributions to the field, based on which the role of sustainable entrepreneurship in the XXI century, research directions and the criticism of sustainable entrepreneurship are identified and discussed. This literature review of research on sustainable entrepreneurship may develop an agenda for future research paths and practice.

Keywords: sustainable entrepreneurship, sustainability entrepreneurship, entrepreneur 